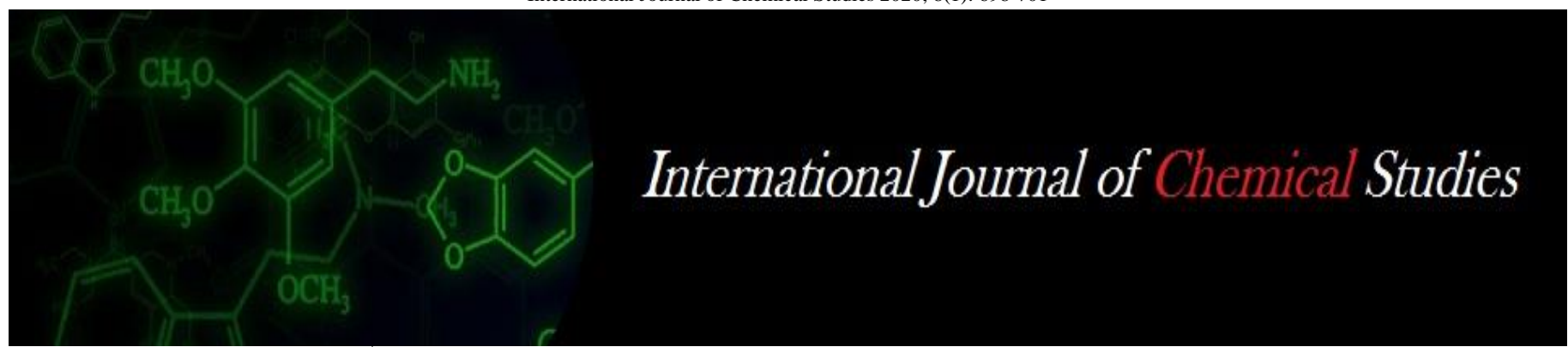

P-ISSN: 2349-8528

E-ISSN: 2321-4902

IJCS 2020; 8(1): 698-701

(C) 2020 IJCS

Received: 28-11-2019

Accepted: 30-12-2019

Sandeep Kumar

Department of Plant Pathology,

S.V.P. University of Agriculture

\& Technology, Meerut,

Uttar Pradesh, India

Gopal Singh

Department of Plant Pathology, S.V.P. University of Agriculture

\& Technology, Meerut,

Uttar Pradesh, India

Ramji Singh

Department of Plant Pathology, S.V.P. University of Agriculture

\& Technology, Meerut,

Uttar Pradesh, India

Prashant Mishra

Department of Plant Pathology,

S.V.P. University of Agriculture

\& Technology, Meerut,

Uttar Pradesh, India

SK Sachan

Department of Entomology,

S.V.P. University of Agriculture

\& Technology, Meerut,

Uttar Pradesh, India

\section{RS Sengar}

Department of Agri.

Biotechnology, S.V.P.

University of Agriculture \&

Technology, Meerut,

Uttar Pradesh, India

\section{Effect of different cereals flour additives on sporophores production of Oyster mushroom (Pleurotus sapidus and Pleurotus flabellatus)}

\author{
Sandeep Kumar, Gopal Singh, Ramji Singh, Prashant Mishra, SK Sachan \\ and RS Sengar
}

DOI: https://doi.org/10.22271/chemi.2020.v8.i1j.8348

\begin{abstract}
Oyster mushroom (Pleurotus sapidus and Pleurotus flabellatus) was observed for production with application of nutritional amendments to the substrates. In present study cereals additives are evaluated for the impact on yield and quality of oyster mushroom. Maximum number (57.75) of sporophore was observed with maximum yield $(723.75 \mathrm{~g} / \mathrm{kg}$ of dry substrate with $72.37 \%$ B.E.) sporophore in wheat straw + Rice flour@ @2.5\%. The minimum yield was found in control (without additive) $(540.00 \mathrm{~g} / \mathrm{kg}$ of dry substrate with 54\% B.E.) in Pleurotus sapidus whole. In case of Pleurotus flabellatus maximum number of sporophore (76.25) and maximum yield $(866.25 \mathrm{~g} / \mathrm{kg}$ of dry substrate with $72.37 \%$ B.E.) was found in wheat straw + Rice flour @2.5\%. The minimum yield was found in control (without additive) $(579.00 \mathrm{~g} / \mathrm{kg}$ of dry substrate) which was found significantly lower than all treatments.
\end{abstract}

Keywords: Cereals flour, additives, Pleurotus spp., number of fruiting bodies and yield

\section{Introduction}

The mushroom is recognized as fleshy macro-fungi, a group of achlorophyllous organisms. Which have umbrella like sporophore (fruiting body) with spores, naturally grown in fields, forests, on manure heaps, water channels and hilly areas, mostly during and just after rains. Since earliest time, the mushrooms have been used as special kinds of food. Pleurotus spp. constitute a cost effective means of both supplementing the nutrition to human kind and alleviating the suffering caused by certain kinds of illnesses. They are considered as one of the four major edible mushrooms cultivated in different countries for human consumption. Mushroom belongs to two of the large classes of fungi i.e., Basidiomystes and Ascomycetes (Webster, 1980; Dix and Webster, 1995) ${ }^{[14,3]}$. In the cultivation of oyster mushroom, most cellulosic farm waste is used as substrate like paddy straw, wheat straw, corncobs, bagasse, banana leaves, waste paper, cotton waste etc. In addition to these existing supplements, the use of low-cost agricultural by-products available at the productive regions is a promising approach. Among others, cereal meals and brans, chicken manure, cottonseed meal, urea, superphosphate, ammonium sulphate, grape pomace, feather flour or defatted meals from dry nuts, are recognized as active ingredients to supplement substrates employed in mushroom cultivation in Brazil or Europe (Zied et al. 2011; Pardo-Giménez et al. 2016, 2018) ${ }^{[15,9,10]}$. Among them wheat straw is found to be best substrate giving more bio efficiency. The chemical composition of the fresh fruiting bodies of oyster mushroom, Pleurotus indicates a large quantity of moisture $(90.8 \%)$, whereas fresh as well as dry oyster mushrooms are rich in proteins $(30.4 \%)$, fat $(2.2 \%)$, carbohydrates $(57.6 \%)$, fiber $(8.7 \%)$ and ash $(9.8 \%)$ with $345 \mathrm{~K}$ (cal) energy value on $100 \mathrm{~g}$ dry weight basis; while vitamins such as thiamin (4.8 $\mathrm{mg})$, riboflavin (4.7 $\mathrm{mg}$ ) and niacin $(108.7 \mathrm{mg})$, minerals like calcium (98 $\mathrm{mg}$ ), phosphorus (476 $\mathrm{mg})$, ferrous $(8.5 \mathrm{mg})$ and sodium $(61 \mathrm{mg})$ on $100 \mathrm{~g}$ dry weight basis, are also found present (Pandey \& Ghosh, 1996). Rambelli \& Menini (1985) ${ }^{[7,11]}$ reported that this mushroom is reputed to be antitumoural because of its chemical composition.
Corresponding Author: Sandeep Kumar

Department of Plant Pathology, S.V.P. University of Agriculture \& Technology, Meerut,

Uttar Pradesh, India 


\section{Materials and Methods}

The present study was conducted during 2018 in Mushroom Laboratory Department Plant Pathology, S. V. P. University of Agriculture and Technology, Meerut, UP, India, which is situated on the Western side of the Delhi-Dehradun high way (NH-58) at a distance of $10.0 \mathrm{~km}$ away in the north of Meerut city.

\section{Mushroom seed (spawn) production}

To prepare the spawn, $1 \mathrm{~kg}$ of wheat grain was soaked in 1.5 litres of water for overnight and excess water was drained from the grains. A quantity of $1 \mathrm{~kg}$ of the soaked grains was mixed with $12 \mathrm{~g}$ of the gypsum and $3 \mathrm{~g} \mathrm{CaCO} 3$. Gypsum prevents the sticking of wheat grains together and calcium carbonate maintains the $\mathrm{pH} 5.5$ - 7.5. The mixture was packed halfway into $500 \mathrm{ml}$ bottles. The bottles were plugged with non-absorbent cotton and covered with butter paper. These bottles were then sterilized at $121^{\circ} \mathrm{C}$ ( $15 \mathrm{lbs}$ pressure) for 2 hours on two consecutive days. Sterilized bottles were taken out from the autoclave, while still hot and were shaken to avoid clumping of grains. Sterilized bottles were inoculated by $9 \mathrm{~mm}$ disc of previously grown pure cultures of Pleurotus spp. in a laminar air flow. The spawn bottles were incubated without shaking at $24 \pm 1{ }^{\circ} \mathrm{C}$ in B.O.D incubator for two weeks until the mycelium had fully colonized the grain.

\section{Mushroom Production \\ Substrate Preparation}

Wheat straw was used as substrate for this experiment. It was soaked wheat straw @ 10kg/100liter water in a tank with solution of Carbendazim @ 8gm/100liter water + Formalin @ $120 \mathrm{ml} / 100$ liter water soaked for $18 \mathrm{hr}$. (tank should be covered with polythene sheet to prevent the evaporation of formalin). Thereafter, straw was taken out from the solution and kept for 2-3 hours to drain out the excess water.

\section{Spawning}

Spawning was done under aseptic condition. Different sterilized cereal grains additives @ 2 and 2.5 percent per $\mathrm{kg}$ was mixed in Wheat straw (substrate) on dry weight basis and $3 \mathrm{~kg}$ substrate (containing $60-75 \%$ moisture) filled in each polythene bags $\left(22 \times 12^{\prime \prime}\right)$ in three replications and made $8-10$ holes in each bags for aeration. After spawning bags were kept in the dark condition in spawn running room.

\section{Spawn run}

The spawn room temperature $\left(22 \pm 2{ }^{\circ} \mathrm{C}\right)$ and relative humidity (60 to 70 percent) was maintained during spawn run. Humidity was maintained by water spraying three times a day. After the compilations of spawn run in the straw it becomes a compact mass which also sticking to the polythene bags and bags polythene were cut and opened for sporophores formation kept in cropping room. At the time of sporophores formation, the windows were kept open for 1-2 hour to provide fresh air, to release $\mathrm{CO}_{2}$ and to maintain the relative humidity at 80-90 per cent inside the crop room. Total cropping period given was about 60 days.

\section{Sporophores production}

After spawn run, compact stack of substrate (wheat straw) were kept in crop room for the sporophores production. The fruiting bodies were started to appear in 6-8 days. The sporophores were harvested 3-4 days after pinhead initiation. These were harvested by one gentle twisting at the base, taking care that the broken stumps were not left there to avoid rotting in the remaining flushes of running crop. 3-4 flushes were taken after that very few fruiting bodies appear. After the first two flushes, the spawn run blocks were over turned to allow the lower surface and the base to produce fruiting bodies. A total time for cropping up to 3rd flush is about 70 days after spawn run. Watering of the crop is quite important which must be done with a mist sprayer. The water spraying should be done by sprinkler on the blocks after the fruit body start coming up but the floor and walls of the mushroom crop room must be kept moist to maintain relative humidity (80-90 per cent) and temperature $\left(22 \pm 2{ }^{\circ} \mathrm{C}\right)$. Adequate ventilation in the crop room was provided by opening the doors and windows at night for a short time. Some diffused light (25003000 Lux) should be allowed to induce fruiting body formation. Sanitation should be maintained strictly to avoid pest incidence.

The observations were recorded as days for spawn run (DFSR), days for first harvesting (DFFH), days for cropping period (DFCP), number of fruiting body per beg (NOFB), stipe length $(\mathrm{cm})$, pilus width $(\mathrm{cm})$, total yield $(\mathrm{gm} . / \mathrm{kg}$ dry straw), average weight of fruiting body $(\mathrm{g} / \mathrm{FB})$ and Biological efficiency (B.E.\%).

\section{Result and Discussion \\ Effect of different cereals flour additive on yield of Pleurotus spp.}

This experiment was conducted to see the effect of different organic additives on spawn run in substrate, days for first harvesting, cropping period, number of fruiting bodies, yield and increases biological efficiency.

The experiments results indicated that $P$. sapidus minimum days for spawn run (15.00 days) were observed at wheat straw + rice flour @ 2.5\% followed by (15.50 days) wheat straw + maize flour@2.5\% and (15.75 days) in wheat straw + rice flour@2.0\% which was significantly less than all treatments. The maximum days for spawn run (21.00 days) were observed in control. The minimum days for first harvesting (22.00 days) were observed at wheat straw + rice flour @ $2.5 \%$ followed by wheat straw + maize flour @ 2.5\% (22.50 days), wheat straw + rice flour @ 2.0\% (22.75 days) and maximum days for first harvesting (28.00 days) observed in control. Minimum days for cropping period were observed at wheat straw + wheat flour @ 2.5\% (63.50 days) followed by wheat straw + maize flour@ 2.0\% (64.50 days), wheat straw +wheat flour@2.0\% (67.50 days) and maximum cropping period (70.00 days) observed in control. Maximum number of fruiting bodies (57.75) was observed at wheat straw + rice flour@2.5\% followed by wheat straw + maize flour@ $2.5 \%$ (57.00), wheat straw + rice flour @ 2.0\% (55.00) and minimum fruiting observed (42.00) observed in control. Maximum stipe length $(11.92 \mathrm{~cm})$ was observed at wheat straw + wheat flour @ 2.0\% followed by $(11.25 \mathrm{~cm})$ in wheat straw + wheat flour@ 2.5\% and $(11.00 \mathrm{~cm})$ in wheat straw + rice flour @ 2.0\%. The minimum stipe length $(9.07 \mathrm{~cm})$ was observed in control. Maximum width $(10.22 \mathrm{~cm})$ was observed at wheat straw + rice flour @ 2.0\% followed by $(9.90 \mathrm{~cm})$ in wheat straw + wheat flour @ 2.5\% and $(8.95 \mathrm{~cm})$ in wheat straw + wheat flour @ 2.0\% and minimum width $(7.22 \mathrm{~cm})$ observed in control. Maximum yield was found in wheat straw + rice flour @ 2.5\% $(723.75 \mathrm{~g} / \mathrm{kg}$ of dry substrate with $72.37 \%$ B.E.) followed by $(650.00 \mathrm{~g} / \mathrm{kg}$ of dry substrate with $65 \%$ B.E.) in wheat straw + maize flour @ 2.5\% and $(648.25 \mathrm{~g} / \mathrm{kg}$ of dry substrate with $64.82 \%$ B.E) in wheat straw + rice flour@2.0\%. The minimum yield was recorded in control (without additive) $(540.00 \mathrm{~g} / \mathrm{kg}$ of dry substrate with 
$54.00 \%$ B.E.) which was significantly lower than all treatments. The results are shown in Table-1.

In case of $P$. flabellatus minimum days for spawn run $(14.75$ days) were observed at wheat straw + rice flour @ 2.5\% followed by wheat straw + maize flour @ 2.5\% (15.75 days) and (16.00 days) wheat straw + rice flour @ 2.0\% which was significantly less than all treatments. The maximum days for spawn run (21.50 days) were observed in control respectively. Minimum days for first harvesting (21.75 days) were observed in wheat straw + rice flour @ 2.5\% followed by (22.75 days) in wheat straw + maize flour @ 2.5\% and $(23.00$ days) in wheat straw + rice flour @ 2.0\% and maximum days for first harvesting (28.50 days) observed in control. Minimum days for cropping period (67.50 days) were observed in wheat straw + maize flour @ 2.0\% followed by (76.00 days) in wheat straw + maize flour@ 2.5\% and (84.25 days) in wheat straw + wheat flour @ 2.5\% and maximum days for cropping period ( 91.50 days) in control respectively. The maximum number of fruiting bodies was observed in wheat straw + rice flour @ 2.5\% (76.25) followed by (74.50) in wheat straw + maize flour @ 2.5\% and (67.25) in wheat straw + rice flour @ 2.0\%. The minimum number of fruiting bodies was observed that in control (46.25) significantly lower than all treatments. The maximum stipe length $(11.72$ $\mathrm{cm})$ was observed in wheat straw + maize flour @ $2.5 \%$ followed by $(11.67 \mathrm{~cm})$ in wheat straw + wheat flour @ 2.5\% and $(11.37 \mathrm{~cm})$ in wheat straw + rice flour @ 2.5\% and minimum stipe length observed in control $(10.62 \mathrm{~cm})$. The maximum width $(9.75 \& 9.75 \mathrm{~cm})$ similar in wheat straw + maize flour @ 2.0\% \& 2.5\% followed by $(9.70 \mathrm{~cm})$ in wheat straw + wheat flour@ 2.0\% and $(8.97 \mathrm{~cm})$ in wheat straw + rice flour @ 2.0\% and minimum width size was observed in control $(8.32 \mathrm{~cm})$. The maximum yield $(866.25 \mathrm{~g} / \mathrm{kg}$ dry wt. substrate with $86.62 \%$ B.E.) was found in wheat straw + rice flour @ 2.5\% followed by $(772.00 \mathrm{~g} / \mathrm{kg}$ with $77.20 \%$ B.E.) in wheat straw + maize flour @ 2.5\% and $(738.50 \mathrm{~g} / \mathrm{kg}$ with $73.85 \%$ B.E.) in wheat straw + rice flour @ 2.0\%. The minimum yield was found in control (without additive) $(579.00 \mathrm{~g} / \mathrm{kg}$ of dry substrate) which was found significantly lower than all treatments. The results are indicated in Table- 2 . According to the above finding results many scientist worked earlier in these topic. Vooticumpee (1996) ${ }^{[13]}$ was reported the average size of pileus and length of $P$. sajor-caju, Pleurotus spp. and P. ostreatus. The pileus diameter 5.95$7.38 \mathrm{~cm}$, and stipe length $1.30-3.95 \mathrm{~cm}$ was in $P$. sajor-caju, $6.23-7.50 \mathrm{~cm}, 1.0-6.21 \mathrm{~cm}$ in Pleurotus spp. and $5.68-6.18 \mathrm{~cm}$, $1.11-5.66 \mathrm{~cm}$ in Pleurotus ostreatus, respectively. Das et. al., (2000) ${ }^{[2]}$ was also reported sporophore diameter of $P$. sajorcaju ranges from $9.08-11.62 \mathrm{~cm}$ while sporophore diameter of $P$. florida ranged from $5.11-8.24 \mathrm{~cm}$ when grown on the wild grasses in winter season. Similar results were also reported that seven species were naming Pleurotus citriopileatus, Pleurotus djamor, Pleurotus Florida, H. ulmarius and Pleurotus sajor-caju selected. In case of $P$. florida produced sporophores with significantly longer stipe $(4.80 \mathrm{~cm})$ which was at par with $P$. sajor caju $(4.70 \mathrm{~cm})$. P. Florida sporophores with maximum pileus width $(7.90 \mathrm{~cm}) P$. Florida produced sporophores with maximum pileus thickness $(6.90$ $\mathrm{mm})$ and it was significantly more than other species. Among these species maximum pileus thickness was observed in case of $P$. florida $(7.10 \mathrm{~mm})$ which was at par with $P$. djamor $(7.00$ $\mathrm{mm})$ Shukla and Jaitly (2011) ${ }^{[12]}$. We are also reported in Pleurotus sapidus maximum stipe length $(11.92 \mathrm{~cm})$ was observed at wheat straw + wheat flour @ 2.0\%. Maximum width $(10.22 \mathrm{~cm})$ was observed at wheat straw + rice flour @ $2.0 \%$. In case of Pleurotus flabellatus maximum stipe length $(11.72 \mathrm{~cm})$ was observed in wheat straw + maize flour @ $2.5 \%$. The maximum width $(9.75 \& 9.75 \mathrm{~cm})$ similar was observed in wheat straw + maize flour@ $2.0 \% \& 2.5 \%$.

Different nitrogen and carbohydrate rich supplements have been evaluated in crops with a substantial impact on mushroom yield and quality; supplementation is farming method based on the physical addition of nutritional amendments, during the process at spawning for mushroom production (Estrada et al.2009; Pardo-Giménez et al. 2012a, 2016) ${ }^{[5,8,9]}$. Maheshwari et al. (2007) ${ }^{[6]}$ reported addition of soybean meal and wheat bran to the substrate, not only increased the yield of $P$. flabellatus but the texture and flavour characteristics are also improved. Baliyan (2008) ${ }^{[1]}$ also reported that addition of organic supplement such as cotton cake, soybean flour, gram powder, wheat bran and corn meal @ 5 per cent of dry substrate significantly increased the yield and reduced spawn run and cropping period of $P$. sajor caju and $P$. sapidus.

Table 1: Effect of different organic additives (Cereals flour) on spawn run, cropping period and yield of oyster mushroom (P. sapidus)

\begin{tabular}{|c|c|c|c|c|c|c|c|c|c|c|}
\hline $\begin{array}{l}\text { S. } \\
\text { No. }\end{array}$ & Treatments & DFSR & DFFH & DFCP & NOFB & \begin{tabular}{|c|} 
Stipe \\
Length $(\mathrm{cm})$ \\
\end{tabular} & $\begin{array}{c}\text { Width } \\
(\mathrm{cm})\end{array}$ & \begin{tabular}{|c|} 
Yield $(\mathrm{g} / \mathrm{kg}$ \\
dry substrate)
\end{tabular} & \begin{tabular}{|c|}
$\begin{array}{c}\text { Average Weight } \\
(\mathrm{gm} . / \mathrm{FB})\end{array}$ \\
\end{tabular} & $\begin{array}{c}\text { Biological } \\
\text { efficiency }(\%)\end{array}$ \\
\hline 1. & $\begin{array}{c}\text { Wheat Straw + Maize Flour } \\
\text { @ 2\% }\end{array}$ & 16.25 & 23.25 & 64.50 & 49.75 & 9.97 & 8.60 & 636.25 & 12.78 & 63.62 \\
\hline 2. & $\begin{array}{c}\text { Wheat Straw + Maize Flour } \\
\text { @ 2.5\% }\end{array}$ & 15.50 & 22.50 & 68.75 & 57.00 & 10.27 & 7.87 & 650.00 & 11.40 & 65.00 \\
\hline 3. & $\begin{array}{c}\text { Wheat Straw + Wheat Flour } \\
@ 2 \%\end{array}$ & 18.25 & 25.25 & 67.50 & 44.25 & 11.92 & 8.95 & 583.75 & 13.19 & 58.37 \\
\hline 4. & $\begin{array}{l}\text { Wheat Straw + Wheat Flour } \\
\qquad 2.5 \%\end{array}$ & 18.00 & 25.00 & 63.50 & 48.25 & 11.25 & 9.90 & 618.75 & 12.82 & 61.87 \\
\hline 5. & $\begin{array}{c}\text { Wheat Straw + Rice Flour @ } \\
2 \%\end{array}$ & 15.75 & 22.75 & 69.25 & 55.00 & 11.00 & 10.22 & 648.25 & 11.78 & 64.82 \\
\hline 6. & $\begin{array}{c}\text { Wheat Straw + Rice Flour @ } \\
2.5 \%\end{array}$ & 15.00 & 22.00 & 69.50 & 57.75 & 10.77 & 8.10 & 723.75 & 12.53 & 72.37 \\
\hline 7. & Control & 21.00 & 28.00 & 70.00 & 42.00 & 9.07 & 7.22 & 540.00 & 12.85 & 54.00 \\
\hline & CD at $5 \%$ & 1.26 & 1.26 & 2.91 & 3.58 & 0.79 & 0.92 & 17.06 & - & - \\
\hline
\end{tabular}

Average of four replications

$\mathrm{DFSR}=$ Days for spawn run, DFFH= Days for first harvesting, DFCP= Days for cropping period, NOFB= Number of fruiting body, 
Table 2: Effect of different organic additives (Cereals flour) on spawn run, cropping period and yield of oyster mushroom (P. flabellatus)

\begin{tabular}{|c|c|c|c|c|c|c|c|c|c|c|}
\hline $\begin{array}{l}\text { S. } \\
\text { No. }\end{array}$ & Treatments & DFSR & DFFH & DFCP & NOFB & \begin{tabular}{|c|} 
Stipe \\
Length $(\mathrm{cm})$ \\
\end{tabular} & $\begin{array}{l}\text { Width } \\
\text { (cm) }\end{array}$ & \begin{tabular}{|c|} 
Yield $(\mathrm{g} / \mathrm{kg}$ \\
dry substrate)
\end{tabular} & $\begin{array}{c}\text { Average Weight } \\
(\mathrm{gm} . / \mathrm{FB})\end{array}$ & $\begin{array}{c}\text { Biological } \\
\text { efficiency }(\%)\end{array}$ \\
\hline 1. & $\begin{array}{c}\text { Wheat Straw + Maize Flour } \\
@ 2 \%\end{array}$ & 16.50 & 23.50 & 87.50 & 66.25 & 10.72 & 9.75 & 712.50 & 10.75 & 71.25 \\
\hline 2. & $\begin{array}{c}\text { Wheat Straw + Maize Flour } \\
\text { @ 2.5\% } \\
\end{array}$ & 15.75 & 22.75 & 76.00 & 74.50 & 11.72 & 9.75 & 772.00 & 10.36 & 77.20 \\
\hline 3. & $\begin{array}{c}\text { Wheat Straw + Wheat Flour } \\
@ 2 \%\end{array}$ & 19.25 & 26.25 & 87.50 & 47.00 & 11.07 & 9.70 & 582.50 & 12.39 & 58.25 \\
\hline 4. & $\begin{array}{c}\text { Wheat Straw + Wheat Flour } \\
\text { @ 2.5\% }\end{array}$ & 18.75 & 25.75 & 84.25 & 65.25 & 11.67 & 8.60 & 702.00 & 10.75 & 70.20 \\
\hline 5. & $\begin{array}{c}\text { Wheat Straw + Rice Flour @ } \\
2 \%\end{array}$ & 16.00 & 23.00 & 90.50 & 67.25 & 11.30 & 8.97 & 738.50 & 10.98 & 73.85 \\
\hline 6. & $\begin{array}{c}\text { Wheat Straw + Rice Flour @ } \\
2.5 \%\end{array}$ & 14.75 & 21.75 & 91.50 & 76.25 & 11.37 & 8.77 & 866.25 & 11.36 & 86.62 \\
\hline 7. & Control & 21.50 & 28.50 & 67.50 & 46.25 & 10.62 & 8.32 & 579.00 & 12.51 & 57.90 \\
\hline & $\mathrm{CD}$ at $5 \%$ & 1.40 & 1.40 & 5.91 & 7.11 & 0.69 & 0.87 & 18.87 & - & - \\
\hline
\end{tabular}

Average of four replications

$\mathrm{DFSR}=$ Days for spawn run, DFFH= Days for first harvesting, $\mathrm{DFCP}=$ Days for cropping period, $\mathrm{NOFB}=\mathrm{Number}$ of fruiting body

\section{Conclusion}

Supplementation is consists of the application of nutritional amendments to the substrates employed for mushroom cultivation. Different nitrogen and carbohydrate rich supplements have been evaluated in crops with a substantial impact on mushroom yield and quality. Thus it can be concluded that in case of different cereals flour the maximal yield $(723.75 \& 866.25 \mathrm{~g} / \mathrm{kg}$ dry substrate) in $P$. sapidus and $P$. flabellatus respectively, minimum days required for spawn run and maximum number of fruiting bodies was founded.

\section{References}

1. Baliyan N. Study of genetic variability, spawn quality and inter specific hybridization of Pleurotus species. Ph. D thesis, SVPUA \& T, Meerut, 2008, 36-54.

2. Das N, Mahapatra SC, Chattopadhyaya RN. Use of wild grasses as substrate for cultivation of Oyster mushroom in south west Bengal. Mushroom Research. 2000; 9(2):95-99.

3. Dix NJ, Webster J. Fungal Ecology, Chapman and Hall Inc., London New York, 1995.

4. Edwards RL. A look at mushroom growing in france and Italy. Mushroom J. 1977; 49:11-14.

5. Estrada AER, Jimenez-Gasco MM, Royse DJ. Improvement of yield of Pleurotus eryngii var. eryngii by substrate supplementation and use of a casing overlay. Bio Resour Technol. 2009; 100:5270-5276.

6. Maheshwari SK, Nazir A, Bhat MA, Beig SDM, Kounser S. Effect of agro-wastes on spawn run, pinhead formation and yield of oyster mushroom (Pleurotus flabellatus) in Kashmir. J. mycol. Pl. pathol. 2007; 37:375-376.

7. Pandey RS, Ghosh SK. A Handbook on Mushroom Cultivation. Emkay publications, Delhi, 1996, 134p.

8. Pardo-Giménez A, Zied DC, Álvarez-Ortí M, Rubio M, Pardo JE. Effect of supplementing compost with grapeseed meal on Agaricus bisporus production. J. Sci Food Agric. 2012a; 92(8):1665-1671.

9. Pardo-Giménez A, Catalán L, Carrasco J, Álvarez-Ortí M, Zied D, Pardo J. Effect of supplementing crop substrate with defatted pistachio meal on Agaricus bisporus and Pleurotus ostreatus production. J. Sci. Food Agric. 2016; 96(11):3838-3845.

10. Pardo-Giménez A, Carrasco J, Roncero JM, Álvarez-Ortí M, Zied DC, Pardo-González JE. Recycling of the biomass waste defatted almond meal as a novel nutritional supplementation for cultivated edible mushrooms. Acta Sci. Agro. 2018; 40:e39341.

11. Rambelli A, Menini UG. Manual on mushroom cultivation. FAO Plant Production and Protection paper: 43, 1985, 65p.

12. Shukla, Shubhra, Jaitly AK. Morphological and Biochemical Characterization of Different Oyster Mushroom (Pleurotus spp.). Journal of Phytology. 2011; 3(8):18-20.

13. Vooticumpee P. Studies on isozyme patterns, morphology, physiology and yield of Pleurotus sajorcaju, Pleurotus sp. and Pleurotus ostreatus. Bankok (Thailand), 1996.

14. Webster J. Introduction to the Fungi. Second Edition, Cambridge University Press, 1980.

15. Zied DC, Savoie JM, Pardo-Giménez A. Soybean the main nitrogen source in cultivation substrates of edible and medicinal mushrooms. In: El-Shemy HA (ed) Soybean and nutrition. In Tech Open Access, Rijeka, 2011, 433-452. 